\title{
WSPÓŁCZESNE PERSPEKTYWY ROZWOJU ZAWODOWEGO W NAUKACH SPOŁECZNYCH
}

Z a ry s tréś c i. W niniejszym artykule zostaną zaprezentowane dwa, w pewnym sensie odmienne, ale współistniejące obecnie konteksty rozwoju. W pierwszym za punkt odniesienia przyjęto perspektywę jednostki, jej wartości i oczekiwania związane z realizacją drogi zawodowej. W drugim zaś, rozwój zawodowy pracownika wpisany został w rzeczywistość organizacji z jej celami, wartościami i procedurami. Rozbieżności między tymi „światami” są na tyle istotne, że skłaniają do głębszej refleksji i udzielenia odpowiedzi na pytanie: jakie warunki powinny być spełnione, by osiągnąć perspektywę integrującą? Jaka powinna być charakterystyka dojrzałego rozwojowo pracownika (aktywnego, świadomego wartości i znaczenia rozwoju) oraz dojrzałej rozwojowo organizacji (stwarzającej warunki rozwoju i do niego zachęcającej), tak by te dwa podmioty mogły z sukcesem i w sposób optymalny osiągnąć swoje cele i zamierzenia.

Słow a kluc zowe: Rozwój zawodowy pracownika, wartości zawodowe, determinanty rozwoju.

\section{WPROWADZENIE}

Rozwój jednostki stanowi przedmiot zainteresowania wielu dziedzin nauki. W naukach ekonomicznych proces ten wpisywany jest w obszar specyficznej działalności człowieka na rynku pracy, związanej z pracą zawodową. Jednak w kontekście interdyscyplinarności tej problematyki zdumiewać musi fakt podejścia fragmentarycznego, gdzie analizie poddawany jest sam rozwój jednostki jako pracownika, z pominięciem innych aspektów jego funkcjonowania. Podobnie zresztą sprawa wygląda w obszarze psychologii, gdzie rozwój zawodowy traktowany jest jako jeden z przejawów aktywności (celowej lub nie) człowieka. 
Takie oddzielne, separatystyczne podejście jest nie tylko nieuzasadnione, ale wręcz szkodliwe, ograniczając skuteczność podejmowanych działań. Nie można bowiem mówić o prawidłowym zarządzaniu rozwojem zawodowym pracownika, gdy zawęża się ono wyłącznie do murów organizacji. Podobnie jak nie można mówić o rozwoju zawodowym człowieka, bagatelizując specyfikę zachowań organizacyjnych. W obszarach tych zbyt wiele zmiennych decyduje o kształcie $\mathrm{i}$ tempie tego procesu (więcej na ten temat por. Januszkiewicz, 2009).

Warto zatem zastanowić się jaki jest kontekst rozwoju zawodowego z perspektywy jednostki. Jakie wartości, cele, oczekiwania obecnie determinują jego przebieg, decydując tym samym o miejscu aktywności zawodowej z życiu człowieka. Z drugiej strony należy również rozważyć, jakie są oczekiwania organizacji względem swoich pracowników. W jaki sposób z jej perspektywy powinien wyglądać rozwój zawodowy pracownika i jego relacje z organizacją.

\section{PERSPEKTYWA JEDNOSTKI}

Częściowa negacja i odrzucenie tradycyjnie określonych form życia sprawia, że człowiek staje się twórcą, konstruktorem, scenarzystą i aktorem w wymiarach własnej biografii. Formułuje ją zgodnie z własną wizją świata, której coraz częściej towarzyszy koncentracja na „tu i teraz”, a przyszłość traktowana jest jako „rozszerzona teraźniejszość” (Por. Mariański, 2006, s. 17-45). Indywidualizacja wartości i wyniesienie własnych potrzeb i aspiracji do rangi sacrum, sprawia, że zmiana stosunku do życia w ogóle, przekłada się również na zmianę postawy wobec jego zróżnicowanych wymiarów.

W aspekcie pracy zawodowej istotnej metamorfozie ulega struktura oczekiwań. Jednostki świadome własnej odrębności i możliwości stwarzanych przez otoczenie, spodziewają się od pracy czegoś więcej niż tylko zaspokojenia podstawowych potrzeb. Nie jest to jednak postawa roszczeniowa, wymagająca natychmiastowego zaspokojenia, lecz nowy rodzaj relacji, w którym jednostka występuje nie jako pracownik, ale jako klient organizacji, oczekujący spełnienia własnych celów.

Oczywiście w dobie kryzysu światowego i przemian społeczno-gospodarczych, którym w dalszym ciągu ulegamy, opis uwzględniający rosnące wymagania jednostki wydaje się odrealniony. Jednak pogłębiona analiza pozwala dostrzec w nim mniej lub bardziej wyraźne odbicie rzeczywistości. Jeśli bowiem mówimy o trudnościach na rynku pracy, to postawa indywidualistyczna tym bardziej wydaje się uzasadniona. W świadomości pracowników zagrożonych utratą pracy, nie ma miejsca na poświęcanie się dla idei ogółu. 
Analizując model zmiany dominujących wartości pracy można zauważyć, iż współczesny pracownik waloryzując swoje potrzeby, realizuje się zawodowo w wymiarze określonym przez cele i wartości jednostkowe (Tabela 1).

W tym kontekście szczególnie wyraźnie zarysowuje się charakterystyka generacji Y, pokolenia milenium, pokolenia doby Internetu. W tym przypadku ewidentnie brakuje miejsca na ideę integracji. Jest to zatem bardziej kalkulatywny niż moralny typ uczestnictwa w organizacji. Uczestnictwo „moralne” polega bowiem na emocjonalnej więzi z organizacją i wynika głównie z potrzeby przynależności, podczas gdy typ „kalkulatywny”, związany jest bardziej z rachunkiem $\mathrm{w}$ jakim stopniu dana organizacja jest w stanie zaspokoić oczekiwania pracownika w zakresie potrzeb podstawowych (płace i inne świadczenia materialne) lub potrzeb wyższego rzędu (prestiż, osiągnięcia zawodowe etc.).

Tabela 1. Zmiany dominujących wartości współczesnych pracowników

\begin{tabular}{|c|c|c|c|}
\hline Etap & Rozpoczęcie pracy & Przeciętny wiek & $\begin{array}{l}\text { Dominujące wartości } \\
\text { pracy }\end{array}$ \\
\hline $\begin{array}{l}\text { Protestancka } \\
\text { etyka pracy }\end{array}$ & $\begin{array}{l}\text { Od połowy lat czterdziestych } \\
\text { do połowy lat pięćdziesiątych }\end{array}$ & $60-75$ & $\begin{array}{l}\text { Pracowitość, konserwatyzm, } \\
\text { lojalność wobec organizacji }\end{array}$ \\
\hline Egzystencjalizm & $\begin{array}{l}\text { Od lat sześćdziesiątych do } \\
\text { połowy lat siedemdziesiątych }\end{array}$ & $45-60$ & $\begin{array}{l}\text { Zainteresowanie jakością życia, } \\
\text { dążenie do samodzielności, } \\
\text { lojalność wobec wartości }\end{array}$ \\
\hline Pragmatyzm & $\begin{array}{l}\text { Od połowy lat siedemdziesiątych } \\
\text { do połowy lat osiemdziesiątych }\end{array}$ & $35-45$ & $\begin{array}{l}\text { Chęć sukcesu i osiągnięć, ambicja, } \\
\text { pracowitość, lojalność wobec } \\
\text { kariery }\end{array}$ \\
\hline Generacja X & $\begin{array}{l}\text { Od połowy lat osiemdziesiątych } \\
\text { do dziewięćdziesiątych lat }\end{array}$ & $35-30$ & $\begin{array}{l}\text { Elastyczność, dążenie do satysfakcji } \\
\text { zawodowej }\end{array}$ \\
\hline Generacja Y & Od dwutysięcznego roku & $30-\ldots$ & $\begin{array}{l}\text { Orientacja zadaniowa, mobilność, } \\
\text { chęć rozwoju, niezależność }\end{array}$ \\
\hline
\end{tabular}

Źródło: opracowanie własne na podstawie: Robbins S.P., Zasady zachowania $w$ organizacji, Wydawnictwo Zysk i S-ka, Poznań 2000, s. 31;

Charakteryzowany w ten sposób typ kalkulatywny można nazwać racjonalnym, pozwala bowiem określić proporcje między własnym wkładem pracy na rzecz organizacji, a korzyściami otrzymywanymi z tego tytułu. Jeśli wynik netto jest dla jednostki niezadowalający, a jednocześnie widzi ona możliwość uzyskania większych osobistych korzyści gdzie indziej, wówczas nie tylko nie może być mowy o zaangażowaniu w wykonywaną pracę, ale również o stałości zatrudnienia, bowiem jednostka bez oporów opuści daną, mało „opłacalną” organizację (Sikorski, 1998, s. 153). 


\section{PERSPEKTYWA ORGANIZACJI}

W drugim z wyróżnionych na wstępie opisów, punkt centralny, wokół którego kształtowane są relacje z pracownikiem stanowią interesy organizacji. Wobec niestałości otoczenia, konieczność realizacji misji i celów wymusza zmiany w strukturze zatrudnienia oraz zarządzania zasobami ludzkimi. Obecnie status stałego pracownika i pracy na tzw. czas nieokreślony zaczyna należeć do przeszłości, a najlepszy kandydat do pracy to ten, który w danej chwili spełnia określone warunki. Takim praktykom sprzyjają coraz częściej wykorzystywane atypowe formy zatrudnienia, wśród których wymienić należy chociażby kontrakty menadżerskie, praca na wezwanie, podwykonawstwo, zatrudnienie rotacyjne (Turska, 2005, s. 257-259). Rola pracownika jest więc w dużej mierze ograniczana przez samą organizację. Jak w tej sytuacji odnaleźć miejsce na wartości społeczne, wspomnianą integracje, czy wspólnotę interesów?

Koncepcją wpisującą się w taką charakterystykę organizacji jest zaproponowany przez M.A Huselid'a., R.W. Beatty i B.E. Becker'a podział na pracowników klasy „A”, „B” i „C” oraz stanowiska klasy „A”, „B” i „C” (Huselid, Beatty, Becker, 2006, s. 78).

Stanowiska klasy „A” określane jako strategiczne, mają bezpośredni wpływ na działalność organizacji, podczas gdy stanowiska „B” (wsparcie), mają pośredni wpływ strategiczny, poprzez wspieranie stanowisk strategicznych i minimalizując ryzyko utraty wartości. Natomiast od stanowisk klasy „C” może zależeć funkcjonowanie firmy, ale mają one niewielki wpływ strategiczny (Rysunek 1).



Rysunek 1. Model klas stanowisk

Źródło: opracowanie własne. 
Podejście to zakłada, iż skoncentrowanie się wyłącznie na pozyskiwaniu pracowników klasy A i zapewnienie im rozwoju, nie jest najlepszą strategią. Obecnie korzystniejszym rozwiązaniem jest zidentyfikowanie kluczowych stanowisk pracy, a następnie podejmowanie takich działań, by właściwi ludzie znaleźli się na właściwych stanowiskach. Jednak powoduje to również inną konsekwencję poza klasą A, różnicowane są również kategorie B i C. Zarządzanie zweryfikowanym w ten sposób portfelem stanowisk, zakłada co prawda ich koordynację, jednak sukces firmy zależy od stanowisk A, dlatego to ich głównie dotyczą inwestycje. Nie oznacza to ignorowania pozostałych grup, przy czym B traktowana jest w sposób szczególny, jako wspierająca A i źródło ewentualnego potencjału sukcesji, natomiast stanowiska klasy $\mathrm{C}$ - jako niestrategiczne, $\mathrm{z}$ czasem proponuje się wyeliminować, bądź przemieścić na zewnątrz.

Autorzy tej koncepcji zaznaczają, iż istnieje zasadnicza różnica między sprawiedliwością a równością w zarządzaniu zasobami ludzkimi. Procedury kadrowe ewoluujące w kierunku równego traktowania wszystkich pracowników, obecnie w dobie wzmożonej konkurencji muszą traktować każdego zgodnie z jego wkładem w osiąganie celów firmy. Takie działania, zmierzające do „rozluźnienia więzi” z pracownikami, podyktowane są oczywiście rachunkiem ekonomicznym. Poprzez elastyczność zatrudnienia/kompetencji i właściwe nimi zarządzanie, organizacja zapewnia sobie współpracę z tymi, którzy aktualnie zaspokajają potrzeby kadrowe. Jednak kategoryzowanie ludzi, tworzenie klas stanowisk pracy, którym zgodnie z przyjętą polityką poświęca się odpowiednią uwagę, czy też czasowe ich wykorzystywanie, zamiast z nowoczesną wizją zarządzania powinno raczej kojarzyć się z jego początkami, i przedmiotowym traktowaniem pracownika.

\section{RAPORT ROZBIEŻNOŚCI}

Trudno oczywiście jednoznacznie rozstrzygnąć, który z prezentowanych opisów jest lepszy, a który gorszy, który sprzyja rozwojowi, a który go hamuje. Tym bardziej, że są to tylko jedne $z$ wielu możliwości. Jednak bez owej konieczności waloryzowania rzeczywistości, należy wskazać, iż charakter relacji pracownik organizacja może przyjąć jedną z trzech form, wynikających ze zróżnicowanej orientacji jednostki na cele.

Zdaniem psychologów koncentrując się na osiągnięciu celu własnego lub celu innych osób, jednostka powoduje powstanie zależności między nimi, prowadzącej do jednej z trzech form zachowań społecznych:

- ORIENTACJI INDYWIDUALISTYCZNEJ, która jest niejako naturalna, pierwotna, jednostce chodzi wyłącznie o dobro jej samej, a interesy innych pozostają bez znaczenia; 
- ORIENTACJI KOOPERACYJNEJ uwzględniającej w różnym stopniu dobro innych, cele „uczestników” są ze sobą pozytywnie sprzężone, zatem realizacja jednego z nich przyczynia się do powodzenia całości;

- ORIENTACJI RYWALIZACYJNEJ, polegającej na dążeniu do zabezpieczenia swoich interesów w relacji do innych, co powoduje, iż cele są sprzężone negatywnie (Por. Reykowski, 1986, s. 135-137).

Oczywiście z punktu widzenia uczestnictwa jednostki w organizacji, najbardziej pożądane są postawy kooperacyjne. Pozytywne sprzężenie celów własnych i celów organizacyjnych pozwala bowiem na zaangażowanie i wzrost poczucia integracji, zmieniając typ uczestnictwa kalkulatywnego na uczestnictwo moralne. Zdaniem Cz. Sikorskiego nie ma jednak problemu wyboru między interesem własnym a interesem grupy, bowiem te dwa rodzaje interesów, są ze sobą zbieżne: im bardziej jednostka koncentruje się na wspomaganiu grupy, tym bardziej sama na tym korzysta. Problemem jest natomiast wybór grupy, która będzie najlepiej sprzyjać zamierzeniom jednostki (Sikorski, 1998, s. 149).

Posługując się metaforą gry organizacyjnej, należy wskazać, iż integracyjny rodzaj relacji między celami jednostki i organizacji, daje możliwość rozstrzygnięcia różnego od zera. Tu każdy może wygrać. Organizacja - zyskując kompetencje i ludzi gotowych rozwijać się w wybranym lub wskazanym kierunku, natomiast pracownik - wsparcie w rozwoju, środowisko sprzyjające realizacji celów, gdzie raz określona ścieżka wciąż ewaluuje, otwierając przed nim nowe możliwości. Aby jednak ta optymistyczna wizja dwóch zwycięskich stron mogła się ziścić, konieczna jest dojrzałość graczy, wyrażana właściwym rozumieniem istoty rozwoju zawodowego, wraz z całym spektrum jego determinant.

\section{DOJRZAŁOŚĆ ROZWOJOWA PRACOWNIKA}

Rozwój jest naturalną konsekwencją życia ludzkiego. O ile jednak charakteryzuje funkcjonowanie każdego człowieka, to należy pamiętać, iż jest również elementem różnicującym jednostki względem siebie. Owa powszechność, a zarazem swoistość procesu, w sposób szczególny widoczna jest w przypadku pracy zawodowej. Wykonując pewne czynności, poszerzając ich zakres, czy wreszcie nabywając nowe umiejętności, pracownik podwyższa swoje kwalifikacje - rozwija się. Istotny jest jednak sposób w jaki ten proces następuje. Czy jest to bierne wykonywanie poleceń, poddawanie się rytmowi zobowiązań, czy też aktywne i świadome kierowanie własną działalnością.

Aktywność własną jednostki uznać należy za najważniejszą z determinant rozwoju zawodowego. Jest ona oczywiście warunkiem niewystarczającym, ale zdecydowanie koniecznym. Właśnie tę cechę należy identyfikować jako przejaw 
dojrzałości do przyjęcia roli wyznaczonej przez teraźniejszość. Roli, w której o sukcesie decyduje nie reaktywne dostosowywanie się do wymagań otoczenia, lecz aktywne działanie pozwalające na wykorzystanie płynących z niego szans.

Z punktu wiedzenia organizacji i zarządzania, wykorzystanie orientacji pracowników na rozwój zawodowy wymaga odpowiedniej promocji i stymulacji. Jest to jednak zadanie trudne, należy bowiem zwrócić specjalną uwagę na dysfunkcje i patologie pojawiające się w obrębie wartości z nią związanych. Do obszarów wymagających szczególnej atencji, zaliczyć należy orientację temporalną, dyspozycję w zakresie odpowiedzialności za własne losy oraz równowagę między życiem osobistym a zawodowym.

Zdaniem M. Straś-Romanowskiej współczesny człowiek żyje pod presją konieczności bycia aktywnym, produktywnym, a zarazem atrakcyjnym zawodowo. Aktywność zewnętrzna sprzyja co prawda przystosowaniu do zmiennych wymagań i osiąganiu sukcesów, ale jednocześnie poprzez narzucone tempo, ogranicza kontakt podmiotu z samym sobą, utrudnia dystansowanie się wobec zdarzeń, wymuszając koncentrację na teraźniejszości (Straś-Romanowska, 2006, s. 21).

Dominującą tendencją staje się więc hedonistycznie zaspokajanie pragnień dnia dzisiejszego, konsumpcjonizm nastawiony na natychmiastową gratyfikację, stojący w oczywistej opozycji do filozoficznych koncepcji rozwoju poprzez kształtowanie idei, osiągania dóbr wyższych (intelektualnych), nawet w dłuższej perspektywie czasu. Oczekiwania wobec jednostki mają charakter pragmatyczny, co powoduje, iż jej aktywność ukierunkowana jest głównie na zadania sprawnościowe, podnoszące kwalifikacje i umożliwiające realizację obecnych zadań. Wzmożona aktywność współczesnego człowieka wymuszona jest więc z jednej strony rosnącymi i zmiennymi wymaganiami, konkurencyjnością na rynku pracy, konicznością rywalizacji, z drugiej natomiast żądzą posiadania i używania dóbr. W rezultacie brakuje zarówno motywacji jak i czasu by zastanowić się nad sensem własnego życia, celowością egzystencji, a refleksja nad sobą w perspektywie przyszłych działań stanowi niezbywalny warunek rozwoju (Straś-Romanowska, 2006, s. 21).

Jednak aby odnieść sukces pracownik musi przyjąć na siebie odpowiedzialność za własne losy. Zamiast przedmiotem musi stać się podmiotem swoich działań. Taka autonomia nie może jednak zamykać się w indywidualizmie, prowadzącym do egoizmu. Jan Paweł II stwierdził, iż „,...) zdobycie wolności połączonej z odpowiedzialnością jest zadaniem, które musi podjąć każdy człowiek" (Jan Paweł II, 1998, s. 23-24.). Zarządzanie własnym rozwojem pozwala na przełamanie temporalnego ograniczenia działania, wykroczenie poza pewną granicę ustala jednocześnie nową, która odtąd będzie normą.

W ramach wymienionych obszarów istnieją oczywiście różnice, zdeterminowane chociażby odmiennością doświadczeń społecznych, politycznych, 
gospodarczych, czy kulturowych. Na zachodzie rozwój zawodowy od lat traktowany jest już jako inwestycja w siebie, droga do samorealizacji, podczas gdy u nas wciąż przeważa podejście roszczeniowe, oczekiwanie na gotowe rozwiązania. Innym przejawem niedojrzałości mogą być zaburzenia proporcji życia osobistego i zawodowego.

Czasami zbytnia autonomia, czy wręcz egoizm, nie pozwala jednostce rozwinąć się zawodowo, bowiem w każdym aspekcie pracy dominują wartości osobiste. Często jednak sytuacja jest odwrotna, to obowiązki zawodowe absorbują aktywność jednostki w stopniu uniemożliwiającym prawidłowe funkcjonowanie poza nią (np. stres, praca w nadgodzinach, wymagania pracy wykraczające poza umiejętności, czy też zjawiska patologiczne jak mobbing). W tej sytuacji konieczne wydaje się osiągnięcie równowagi w zakresie relacji praca zawodowa życie osobiste (por. Rysunek 2). Stan określany jako „pożądany”, będzie jednak miał inną charakterystykę dla każdej jednostki, w zależności od wyznaczonych przez nią priorytetów i wartości. Należy jednak pamiętać, że w życie człowieka w sposób naturalny wpisana jest praca, jednak nade wszystko, praca jest „dla człowieka”, a nie człowieka „dla pracy” (Adamkiewicz, 2005, s. 76).

Dojrzałość jednostki w zakresie rozwoju zawodowego stanowi zatem wyraz ogólnego stanu jej dojrzałości. Nabywana wiedza i doświadczenie nie stanowią bowiem prostej sumy poszczególnych wartości. Nie jest to zależność addytywna, lecz systemowa. Tak więc chcąc wykorzystać potencjał rozwojowy pracownika należy zwrócić uwagę na wszystkie aspekty jego funkcjonowania jako jednostki, a nie tylko na jego życie zawodowe. Dopiero wówczas, dysponując potrzebnymi informacjami można sprawnie i skutecznie inicjować i stymulować orientację pracownika na rozwój zawodowy.

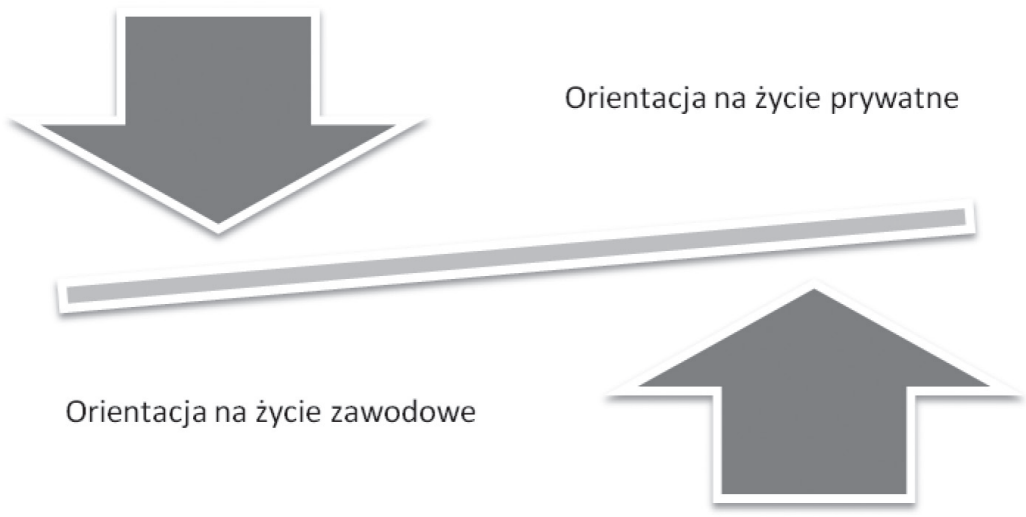

Rysunek 3. Próba osiągnięcia równowagi

Źródło: opracowanie własne 


\section{DOJRZAŁOŚĆ ROZWOJOWA ORGANIZACJI}

Rozwój pracownika w kierunku określonych wartości wymaga ze strony organizacji świadomego, celowego, ukierunkowanego i systematycznego oddziaływania na jego zachowanie (Borkowski, 2003, s. 222). Jako czynniki organizacyjne wpływające na rozwój pracownika zdiagnozować należy kulturę organizacyjną, organizację procesów pracy, relacje przełożony - podwładny oraz zarządzanie zasobami ludzkimi. Rekomendowane kierunki zmian w tych obszarach wymagają jednak działań zintegrowanych, opartych na wspólnych wartościach i wspólnej wizji dotyczącej przyszłości. Z uwagi na swoistość relacji, systemowy charakter działań podejmowanych w tym zakresie, wydaje się więc niezbędny. Nie można bowiem wprowadzić idei partycypacji pracowniczej, czy decentralizacji uprawnień decyzyjnych, bez akceptacji kadry zarządzającej. Podobnie szkolenie pracowników, bez ich osobistego przekonania o korzyściach płynących z tego procesu oraz wsparcia ze strony kierownictwa, nie może przynieść pozytywnych rezultatów.

Powyższe przesłanki skłaniają zatem do stwierdzenia, iż przejawem dojrzałości rozwojowej organizacji będzie inicjowanie i stymulowanie orientacji pracownika na rozwój zawodowy, poprzez systemowe działania w zakresie tworzenia środowiska sprzyjającego rozwojowi. Pozostaje jednak pytanie w jaki sposób osiągnąć pożądaną spójność, szczególnie, gdy dotyczy tak wielu zróżnicowanych obszarów? Cała trudność polega bowiem na tym, iż poszukiwane rozwiązanie powinno z jednej strony charakteryzować działanie szczegółowe, modyfikujące konkretne elementy (np. udział pracowników w podejmowaniu decyzji), zaś z drugiej - ogólne, ujednolicające wprowadzane modyfikacje.

Jak już zostało wspomniane na wstępie, w literaturze przedmiotu problematyka rozwoju pracownika podnoszona jest bardzo często. Są to jednak zazwyczaj opracowania dotyczące wybranych obszarów funkcjonowania organizacji i jako takie, zawierają opis technik i metod właściwych tylko dla nich. Stosunkowo mało jest natomiast pozycji zakładających podejście kompleksowe. Wśród nich, jako najbardziej korespondujące $\mathrm{z}$ omawianą tematyką, wyróżnić należy analizowaną przez M. Czerską koncepcję „korekty kursu”, odnoszącą się do zmiany kultury organizacyjnej. Właściwie zaplanowana i odpowiednio przeprowadzona zmiana kultury organizacyjnej przynosi bowiem nie tylko efekt długookresowy, ale również tak pożądaną, systemową metodologię działań.

Przyjmując, iż żadna zmiana organizacyjna nie może być skutecznie wprowadzona bez zmiany w zakresie kultury organizacyjnej, należy również uznać zależność odwrotną, iż żadna zmiana w zakresie norm i wartości, nie pozostaje obojętna dla wskazanych obszarów organizacji. Zależność tę wykorzystuje 
właśnie podejście „korekty kursu”, które należy rozumieć jako system celowo dobranych metod zarządzania, mających zdolność korygowania kultury organizacji, którego ostateczny efekt jest wypadkową całego zbioru działań (Czerska, 2003, s. 68).

Proces korekty kursu jest zjawiskiem złożonym i warunkowanym przez szereg czynników leżących zarówno po stronie organizacji jak i poza nią. Analiza stanu obecnego i zestawienie go ze stanem pożądanym, dostarcza informacji na temat charakteru i rozmiaru rozbieżności. Taka konstatacja jest podstawą do opracowania kompleksowego planu działania, uwzględniającego zmiany w zakresie: rozwiązań organizacyjnych, form pracy kierowniczej oraz zarządzania zasobami ludzkimi (Czerska 2003, s. 102-105). W każdej ze wskazanych grup, można wymienić obszary mające szczególnie silny wpływ na kulturę organizacji (Tabela 2).

Tabela 2. Metody korekty kursu

\begin{tabular}{|l|l|l|}
\hline \multicolumn{1}{|c|}{ Rozwiązania organizacyjne } & \multicolumn{1}{|c|}{ Formy pracy kierowniczej } & \multicolumn{1}{|c|}{ Zarządzanie zasobami ludzkimi } \\
\hline - Filozofia struktury \\
$\begin{array}{l}\text { organizacyjnej } \\
\text { - Poziom decentralizacji }\end{array}$ & $\begin{array}{l}\text { Tworzenie i upowszechnianie } \\
\text { misji i wizji firmy }\end{array}$ & $\begin{array}{l}\text { - Proces rekrutacji } \\
\text { - Oceny pracownicze }\end{array}$ \\
- Poziom formalizacji & - Wprowadzanie przez kierownika & - Szkolenia \\
- Zarządcza partycypacja & - Osobisty praktów & - System motywacji \\
pracownicza & - Styl kierowania & Outplacement \\
- Więzi komunikacyjne & - Forma kontroli menadżerskiej & \\
\hline
\end{tabular}

Źródło: Czerska M., Zmiana kulturowa w organizacji. Wyzwania dla współczesnego menedżera, Wydawnictwo Diffin, Warszawa 2003, s. 102.

Korekcja kultury organizacyjnej uwzględniająca kierunki zmian, zawsze będzie przebiegać w jednym kierunku: od kultury o niskiej tolerancji niepewności w stronę kultury wysokiej tolerancji niepewności. Ponieważ sam proces przechodzenia od pierwszej charakterystyki, do drugiej, nie stanowi przedmiotu niniejszego opracowania, uzasadnione wydaje się, by pomijając wszelkie aspekty metodologiczne, skierować uwagę w stronę systemowego charakteru owych działań, omawiając go na przykładzie wybranych czynników: szkolenia i motywacji (Tabela 3).

Funkcjonowanie organizacji określonej jako „A” opiera się na zaspokajaniu aktualnych potrzeb, podczas gdy organizację określoną jako „B”, cechuje podejście strategiczne, zorientowane przyszłościowo. Podstawową konsekwencja takich działań jest zmiana stosunku do pracowników i formułowanie wizji długookresowej współpracy, z perspektywą rozwoju nie tyko organizacji, ale również zatrudnianych przez nią osób. 
Tabela 3. Kierunki oddziaływania wybranych metod korekty kursu na kulturę organizacyjną

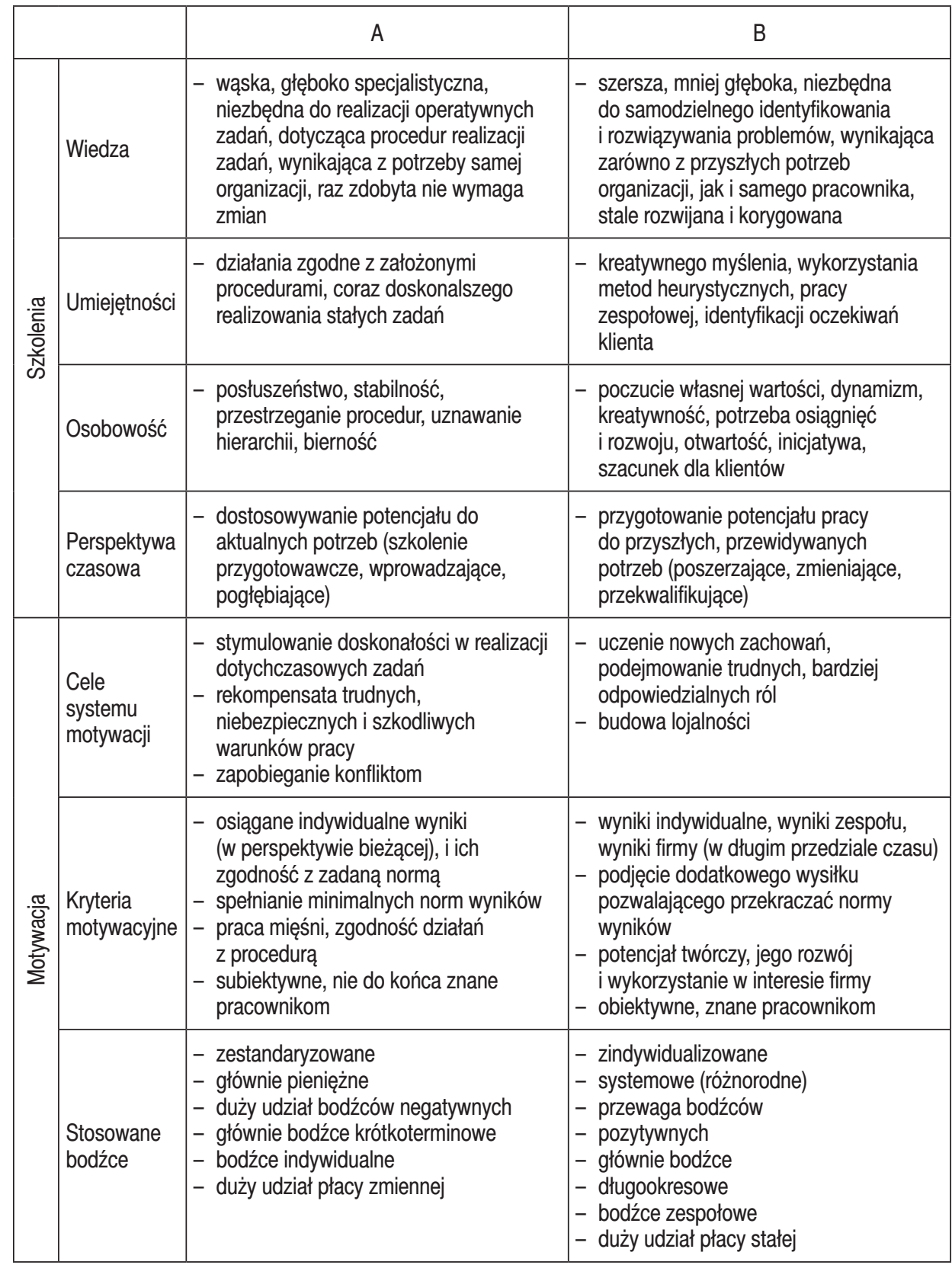

Źródło: Opracowanie własne na podstawie: Czerska M., Zmiana kulturowa w organizacji. Wyzwania dla współczesnego menedżera, Wydawnictwo Difn, Warszawa 2003, s. 117, 119. 
Należy zwrócić uwagę, że im bardziej proces szkolenia i motywacji pracowników zbliżać się będzie do modelu określonego jako „B”, w tym większym stopniu organizacja może liczyć na wzrost integracji między samymi pracownikami oraz pracownikami a instytucją, zmniejszenie oporu wobec proponowanych zmian, wzrost poczucia bezpieczeństwa i pewności zatrudnienia, pracę zespołową, uznanie wiedzy i kompetencji za istotne źródło władzy, wzrost kreatywności oraz elastyczności pracowników, orientację prorozwojową pracowników, związaną z koniecznością samodzielnego wykonywania nowych zadań (Por. Czerska 2003, s. 120).

Nietrudno oczywiście antycypować jakie dodatkowe korzyści w pozostałych obszarach funkcjonowania organizacji, mogą wynikać z takiej modyfikacji jej kultury. Jednak jako najważniejszą z potencjalnych korzyści wymienić można wzrost jakości życia wynikający z poprawy warunków pracy oraz pojawienie się perspektywy rozwoju dla pracownika, skłaniającej go do integracji celów osobistych z planami organizacyjnymi.

Zaprezentowana koncepcja korekty kursu, nie jest ani jedyną, ani uniwersalną metodą osiągania pożądanego modelu organizacji. O jej umieszczeniu w tym miejscu rozważań zadecydował fakt, iż tak wyraźnie w proponowanej metodologii działań akcentuje ich systemowy charakter. Jest to zatem jedna z propozycji kierunku jaki powinny przyjąć organizacje kształtując środowisko sprzyjające rozwojowi pracownika.

\section{ZAKOŃCZENIE}

W niniejszym artykule zaprezentowane wybrane aspekty rozwoju zawodowego, celowo koncentrując się na rozbieżnościach w perspektywie pracownika i organizacji. Takie nieco przerysowane podejście skłania do refleksji w jakim kierunku może zmierzać lub zmierza jednostka i organizacja. Czego przede wszystkim powinna dotyczyć akomodacja i asymilacja. Czy dojrzałość rozwojowa organizacji, oznacza akceptację zależności między rozwojem organizacji a rozwojem pracownika, stworzenie takiego środowiska pracy, które poprzez kompleksowe działania sprzyjać będzie realizacji celów organizacji, dając tym samym podstawę do rozwoju tworzących ją ludzi? Odpowiedź na tak postawione pytanie jest tylko pozornie łatwa i możliwa do przewidzenia. To w rozważaniach teoretycznych głównie podkreśla się znaczenie owej zależności. Praktyka, o czym świadczą analizy materiałów źródłowych i współczesne tendencje w zarządzaniu organizacją jest jednak nieco odmienna. Zmienia się świat i wartości człowieka, podobnie jak zmieniają się cele i środowisko organizacji. Należy jednak pamiętać, że podjęcie działań zmierzających do integralnego rozwoju, może 
doprowadzić do tak pożądanego z punktu widzenia obydwu stron, pogłębienia więzi między pracownikiem a organizacją. $\mathrm{W}$ tej sytuacji podjęcie problematyki dojrzałości rozwojowej pracownika i dojrzałości rozwojowej organizacji należy potraktować jako wyzwanie rzucone przyszłości, którego podjęcie zapobiegnie absolutnej dominacji jednego z dwóch zaprezentowanych na wstępie charakterystyk i prawdopodobnie zwiększy satysfakcję obydwu podmiotów.

\section{LITERATURA}

Adamkiewicz J. (2005), Praca zawodowa problemem życia rodzinnego, [w:] Pietrulewicz B., Wspótczesne problemy edukacji, pracy $i$ zatrudnienia pracowników, Zakład Poligrafii EURODRUK, Zielona Góra.

Borkowski J. (2003), Socjologia i psychologia spoleczna, Wydawnictwo Wyższej Szkoły Humanistycznej im. A. Gieysztora, Pułtusk.

Czerska M. (2003), Zmiana kulturowa w organizacji. Wyzwania dla wspótczesnego menedżera, Wydawnictwo Difin, Warszawa.

Huselid M.A., Beatty R.W., Becker B.E. (2006), Gracze klasy A czy stanowiska klasy A. Nowe strategiczne podejście do zarzadzania zasobami ludzkimi, „Harvard Business Review Polska" 11.

Jan Paweł II (1998), L'Osservatore Romano, 19, nr 3, L'Osservatore Romano - All rights reserved, www.vatican.va/news -archiwum.

Januszkiewicz K. (2009), Rozwój zawodowy pracowników. Szanse i zagrożenia, Wydawnictwo Uniwersytetu Łódzkiego, Łódź.

Mariański J. (2001), Kryzys moralny czy transformacja wartości?, Towarzystwo Naukowe KUL, Lublin.

Reykowski J. (1986), Motywacja, postawy prospoleczne a osobowość, Państwowe Wydawnictwo Naukowe, Warszawa.

Sikorski Cz. (1998), Ludzie nowej generacji. Wzory kultury organizacyjnej wysokiej tolerancji niepewności, Wydawnictwo Uniwersytetu Łódzkiego, Łódź.

Straś-Romańska M. (2006), Niektóre cywilizacyjne zagrożenia dla rozwoju osobowego, [w:] Klebaniuk J. (red.), Człowiek wobec masowych zjawisk społecznych, Oficyna Wydawnicza ATUT, Wrocław.

Turska E. (2005), Globalizacja a restrukturyzacja a nowy model kariery $i$ sukcesu, [w:] Kożusznik B., Kapitał ludzki w dobie integracji i globalizacji, Wydawnictwo Uniwersytetu Śląskiego, Katowice.

Włodarski Z., Człowiek jako wychowawca i nauczyciel (1992), Wydawnictwo WSIP, Warszawa. 


\section{CONTEMPORARY PERSPECTIVES OF CAREER DEVELOPMENT}

Abstract. In this article, will be presented two, in a certain sense different, but co-existing contexts of development. In the first case, reference point is adopted as a perspective of individuals, their values and expectations related to career paths realization. In the second case employee's career development is connected to organization reality with it's goals, values and procedures.

Differences between this two "worlds" are enough relevant for deep reflection and answer the question: what kind of conditions should be met in order to achieve integration perspective? What should be the characteristics of well developed employee (active, aware of the value and importance of developing) and well developed organization (creating condition for employees' development and stimulating them) in order to achieved successfully and in optimal way goals and targets.

Key words: employee's career development, professional value, determinants of development 